\title{
Natural ventilation and indoor air quality in multi-family residential buildings - an indication of the problem, case study
}

\author{
Magdalena Stolarska1, Piotr Lis ${ }^{2}$
}

\begin{abstract}
:
Existing and designed residential buildings should provide the residents with appropriate indoor microclimatic conditions. Both in terms of thermal comfort and indoor air quality. Strong tendencies towards saving energy in buildings contribute to the use of materials with better thermal insulation (walls) and airtightness coefficients (doors and windows). In the last few years there has been a tendency towards air-tight sealing of buildings. This phenomenon can be seen both in older buildings being refurbished as well as in those that are new or thermally-upgraded. At the same time, in existing and new buildings traditional, gravity ventilation is used, and is becoming an extremely important factor in achieving the required indoor conditions. The following are some of the results of the research on this subject, which will, hopefully, provide new insight. The paper describes the use of new technologies, such as hybrid ventilation, in existing buildings. The results presented herein have been achieved from comprehensive measurements in the buildings with natural and hybrid ventilation. The aim of the paper is to present and summarize preliminary studies describing the influence of natural and hybrid ventilation as well as airtightness on an indoor environment.
\end{abstract}

\section{KEYWORDS:}

indoor air quality; natural ventilation; hybrid ventilation; multi-family buildings

\section{Introduction}

The American Society of Ventilation Engineers defines ventilation as a process of forced air exchange in a room, implemented in order to refresh it by removing pollutants. Therefore, providing the required amount of fresh air in a room (or building) is considered to be the main objective of an effective ventilation systems. Nowadays, designing and using ventilation systems in buildings is a necessity. In modern societies, the vast majority of people spend about $2 / 3$ of their lives in enclosed areas [1], i.e. in residential buildings, work and study rooms, commercial and other facilities. These buildings are intended, on the one hand, to protect users from the direct effects of changing outdoor climatic conditions and, on the other hand, to provide an adequate supply and quality of indoor air (IAQ) in the room.

Excessive and uncritical airtight sealing of buildings as well as attempts to drastically reduce the fresh air exchanges which results from implementation of a heating energy saving programme have a negative impact on the quality of air in rooms and thus on their microclimate. In the long term such a situation brings about so-called sick-building syndromes which cause many health problems [2].

${ }^{1}$ PhD student, Czestochowa University of Technology, Faculty of Infrastructure and Environment, ul. J.H. Dąbrowskiego 73, 42-201 Częstochowa, e-mail: m.stolarska@is.pcz.pl

2 Czestochowa University of Technology, Faculty of Infrastructure and Environment, ul. J.H. Dąbrowskiego 73, 42-201 Częstochowa, e-mail: piolis@is.pcz.pl, orcid id: 0000-0002-5310-0895 
The term sick-building syndrome refers to the increase in detrimental symptoms caused by staying in rooms and buildings that can lead to weakness or even illness. This combination of ailments, called a syndrome, includes irritation of the eyes, respiratory tract or skin, nausea and headaches, discomfort, irritation, fatigue and concentration problems. These symptoms are closely related to an improper microenvironment, especially poor air quality. Studies have shown that excessive airtight sealing of a building without ensuring a properly functioning ventilation systems may cause illnesses and ailments in up to $80 \%$ of the people staying in such a building $[2,3]$.

\section{Ventilation and air quality}

\subsection{Indoor and outdoor air pollution}

The dominant influence on the quality of indoor air is exerted by pollution [4], which occurs in the ventilated rooms. Figure 1 presents a simplified balance of pollutants.

The main source of pollution are the users of rooms themselves and their activities. The presence of the users cause changes of the air parameters as a result of heat, moisture and the carbon dioxide they produce [5]. Other (not human) pollutants, which are often toxic (e.g. carbon monoxide, as a result of incomplete combustion processes, smoking, etc.) can occur in high concentrations and also have a significant impact on the air quality. However, even a relatively low concentration of these pollutants can have a negative impact on the health and well-being of the people staying in a ventilated room [6]. Significant sources of pollution in buildings are devices, such as printers and photocopiers in office rooms. The folowing studies $[1,7]$ state that they also include building materials, elements of interior design, and even ventilation or air-conditioning systems. Moreover, cigarette smoke containing several thousand carcinogenic substances is an important source of a very large number of volatile substances harmful to health.

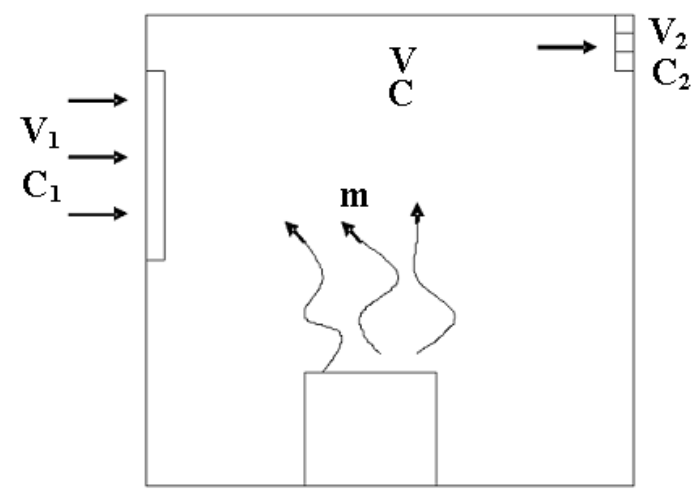

Fig. 1. Balance of indoor pollutants: $\mathrm{V}$ - cubic capacity $\left[\mathrm{m}^{3}\right], \mathrm{C}-$ concentration of the pollutant in the room $\left[\mathrm{kg} / \mathrm{m}^{3}\right], \mathrm{m}$ - flux of pollutants produced in the room $\left[\mathrm{m}^{3} / \mathrm{s}\right], \mathrm{V} 1$ and $\mathrm{V} 2$ volume of air supplied and extracted from the room, C1 and C2 - concentration of pollutants in the incoming and outgoing air

A separate group consists of pollutants introduced into a room together with the outdoor air, whereby air pollution is considered to be any air component that causes deviations from the normal chemical composition of the atmospheric air.

According to the literature, atmospheric air is a mixture of nitrogen and oxygen. Nitrogen is $78 \%$ and oxygen $21 \%$ of the air volume. The remaining $1 \%$ contains carbon dioxide, water vapour, argon and other gases. Air pollution includes compounds contained in exhaust fumes, pollen, water vapour, but also its natural components $\left(\mathrm{O}_{2}, \mathrm{~N}_{2}, \mathrm{CO}_{2}\right)$, if their share of the outdoor air is different from that of the proper chemical air composition. 
Oxygen is the most important component of air. Its amount can drop from 21 to $16 \%$, without any noticeable deterioration in well-being. Nitrogen is normally neutral to the human body because it does not participate in human biological processes. The carbon dioxide content of indoor air is greater than that of outdoor air due to the fact that the air exhaled by humans contains about $4 \%$ of this gas. Increasing the carbon dioxide content to $2.5 \%$ is not harmful to health. At higher concentrations, headaches, tinnitus and accelerated heartbeat occur. Increasing the carbon dioxide content to $18 \%$ is life-threatening [4]. In addition, users are exposed to dust, pollen, fungal and mould spores, as well as chemical pollutants from building materials and home furnishing. Many life-threatening harmful substances are not perceived by humans. They are odourless or colourless, their harmful effects on the human body can be misleading, and some of the diseases caused by them can only be disclosed after many years.

Sources of air pollutant emissions in residential areas include:

- users (residents),

- cooking, washing and cleaning, bathing,

- smoking,

- combustion processes,

- household chemicals (cleaning and laundry products, sprays, cosmetics),

- evaporation of solvents in adhesives, paints, varnishes, furniture, carpets and textiles,

- dust from textiles and home furnishings,

- mites and spores,

- pets.

Due to the above-mentioned sources of pollution in rooms, lack of ventilation or inadequate and ineffective ventilation may lead to symptoms of disease in users, such as: headaches and dizziness, weakness and general exhaustion, irregular heartbeat, irritation of eye, nose and throat mucous membranes, commonly referred to as "sick building syndrome" [8].

\subsection{Ventilation requirements and indoor air quality for residential buildings}

Ventilation requirements for ventilation in residential buildings are regulated by the PN-83/B-03430/Az3:2000 standard: Ventilation in collective residential and public utility buildings [9]. A standard example of ventilation systems commonly used in residential buildings is the so-called gravity (natural) ventilation, which occurs due to the difference in temperature (density) of outdoor and indoor air.

The required air streams, depending on the intended use of the rooms, are as follows:

- kitchen with gas stove $-70 \mathrm{~m}^{3} / \mathrm{h}$;

- kitchen with electric cooker $-50 \mathrm{~m}^{3} / \mathrm{h}$;

- bathroom - $50 \mathrm{~m}^{3} / \mathrm{h}$;

- toilet $-30 \mathrm{~m}^{3} / \mathrm{h}$;

- living room $-30 \mathrm{~m}^{3} / \mathrm{h}$;

- auxiliary room (without window) $-15 \mathrm{~m}^{3} / \mathrm{h}$;

- hall - $15 \mathrm{~m}^{3} / \mathrm{h}$

The streams can also be referred to as "number of exchanges". One "exchange" corresponds to a room volume and the amount of air that must be exchanged within an hour. Requirements for multi-family buildings are the following:

- cellar - 0.3 exchange per hour;

- laundry room - 2.0 exchange per hour;

- drying room - 1.0 exchange per hour;

- staircase $-0.4 \div 0.6$ exchange per hour.

In buildings not higher than 9 storeys natural or mechanical ventilation may be used; in case of higher buildings mechanical ventilation is necessary, preferably supply and extract ventilation, where both removal and supply of air is forced by ventilation units.

In view of the threats to health and even life presented above, the supply of an adequate amount of ventilation air of the desired composition is a basic requirement $[4,10]$. Therefore, 
energy savings in ventilation and air-conditioning should be regarded as half measures, not always well-understood by designers, contractors and users.

Where a ventilation system is used in a building, priority should be given to providing a sufficient amount of ventilation air to ensure the desired level of quality of the indoor air. If it concerns outdoor air only, attention should be paid to its pollution causing further decrease of air quality [4]. Assessment of the impact of air pollution on human health has been the subject of intensive interdisciplinary research in recent years. The results of a number of studies indicate that undoubtedly in the temperate climate zone the predominant share in the group of threats to human health and life caused by air pollution, is accounted for by human occupancy in buildings $[11,12]$. This view was formally confirmed in the resolution of the World Health Organisation, which recognised indoor air quality as an important factor affecting the health of the population as a whole.

\section{Research}

In May 2017, a series of measurements was carried out in a multi-family, 5-storey residential building with two staircases, located in Ruda Śląska at ul. Magazynowa [based on 13].

The measurements were carried out in two series in both staircases at the same time, with one staircase (no. 1) equipped with gravity ventilation [6], with brick ducts for gravity ventilation in kitchens and bathrooms, and the other staircase (no. 2) equipped with a supply and exhaust system of hybrid ventilation. In this ventilation with a balanced pressure system, the ventilation air was supplied through humidity sensitive air inlets, built in the windows of residential rooms, and exhausted through grills and brick ducts of gravity ventilation. Ventilation duct complexes were equipped with hybrid cowls, located on the roof of the building. Additionally, in order to prevent the occurrence of negative pressure in the staircase, the staircase has been unsealed by the use of humidity sensitive air inlets in the entrance doors and windows. The apartments were equipped with instantaneous water heaters for municipal water, located in the bathrooms, where the measuring devices were also located. The diagrams below show the results of measurements carried out in two apartments, located on the same (3rd) floor, in the same way in relation to each other, but in two different staircases. The measurements were carried out on the 8th of May, continuously, every 5 minutes. In addition, there was also a continuous measurement of humidity and temperature in the apartments in question.

Table 1

Technical parameters of the recorder

\begin{tabular}{|c|c|}
\hline \multicolumn{2}{|c|}{ Temperature measurement } \\
\hline Measuring range & $-40-70^{\circ} \mathrm{C}$ \\
\hline Measuring unit & ${ }^{\circ} \mathrm{C}$ \\
\hline Resolution & 0.1 \\
\hline Accuracy & $\begin{array}{l}\text { in the range between }-40-10^{\circ} \mathrm{C} \pm 2.0^{\circ} \mathrm{C} \\
\text { in the range between }-10-40^{\circ} \mathrm{C} \pm 1.0^{\circ} \mathrm{C}\end{array}$ \\
\hline \multicolumn{2}{|c|}{ Moisture measurement } \\
\hline Measuring range & $0-100 \% \mathrm{RH}$ \\
\hline Measuring unit & $\% \mathrm{RH}$ \\
\hline Resolution & $0.1 \% \mathrm{RH}$ \\
\hline Accuracy & $\begin{array}{l}\text { in the range between } 0-20 \% \mathrm{RH} \text { and } 80-100 \% \mathrm{RH} \pm 5 \% \\
\text { in the range between } 20-40 \% \mathrm{RH} \text { and } 60-80 \% \mathrm{RH} \pm 3.5 \% \\
\text { in the range between } 40-60 \% \mathrm{RH} \pm 3 \%\end{array}$ \\
\hline DATA LOGGER & $\begin{array}{l}\text { storage capacity up to } 32.000 \text { results in the device memory; } \\
16.000 \text { entries for temperature and } 16.000 \text { entries for humidity. }\end{array}$ \\
\hline Sampling time & 2, 5, 10, 30 s.; 1, 5, 10, 30 min; 1, 2, 3, 6, 12, 24 hrs. \\
\hline
\end{tabular}



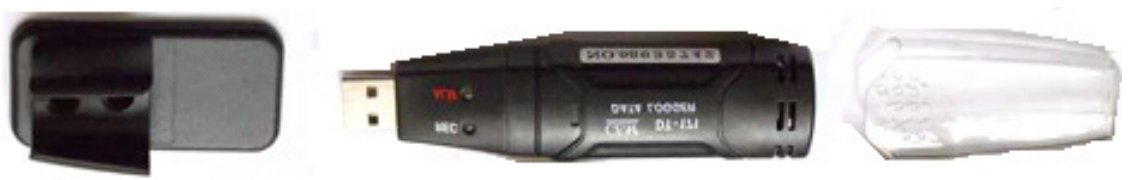

Fig. 2. Temperature and humidity recorder [www.conradelectronic.pl]

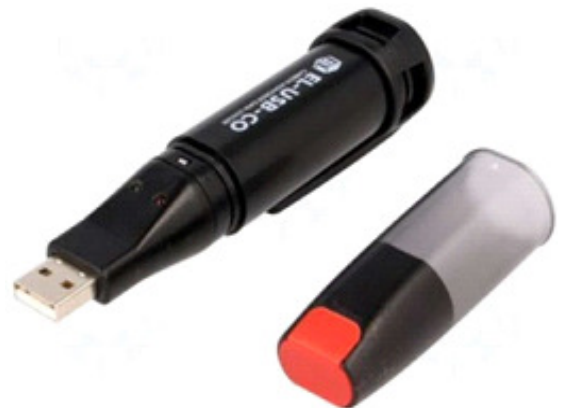

Fig. 3. Carbon monoxide recorder [www.conradelectronic.pl]

The measurements were carried out in bathrooms in both apartments. The sensor was located at a height of about 1.2-1.5 m from the floor level, with free access to it from each side, in order to obtain the most reliable measurement result.

Measurements of air temperature and humidity in the apartments in question were carried out by means of a portable temperature and humidity recorder. DATALOGGER ST-171 records temperature in the range from -40 to $+700^{\circ} \mathrm{C}$ with $0.1 \mathrm{~K}$ resolution and basic accuracy $\pm 1 \%$, and relative humidity in the range from 0 to $100 \%$ with $0.1 \%$ resolution and basic accuracy $\pm 2 \%$ (Fig. 2 and Table 1). The results are stored in internal memory with a capacity of 32,000 measurement data: 16,000 measurement data for temperature and 16,000 measurement data for humidity. Programming the recorder, e.g. setting the sampling time, alarm thresholds and presentation of the results is done using a computer, after installing the software supplied with the recorder and connecting the recorder to the USB port. Sampling time can be set from 10 seconds to 5 minutes. The diagrams below show the results of the measurements for two apartments located on the same (3rd) floor, in the same way in relation to each other, but in two different staircases. The measurements were carried out on the 8th of May, continuously, every 5 minutes. In addition, there was also a continuous measurement of humidity and temperature in the apartments in question.

Measurements of carbon monoxide concentration in the apartments in question were carried out by means of a portable carbon monoxide recorder designed to monitor and record carbon monoxide levels for the purposes of subsequent analysis. The recorder measures the concentration of carbon monoxide in the range from 3 to $1000 \mathrm{ppm}$ with a resolution of $0.5 \mathrm{ppm}$ and a basic accuracy of $\pm 6 \%$ (Fig. 3). The results are stored in the internal memory with a capacity of 32,510 measurement data. Programming the recorder, e.g. setting the sampling time, alarm thresholds and presentation of the results is done using a computer, after installing the software supplied with the recorder and connecting the recorder to the USB port. Sampling time can be set from 10 seconds to 5 minutes.

\section{Research results and discussion}

On the basis of the measurements the following results were obtained: in staircase no. 1 (with natural ventilation) a significant increase in the carbon dioxide concentration level was observed (Fig. 4) and small concentrations of carbon monoxide CO were observed in the bathrooms (Fig. 5). 


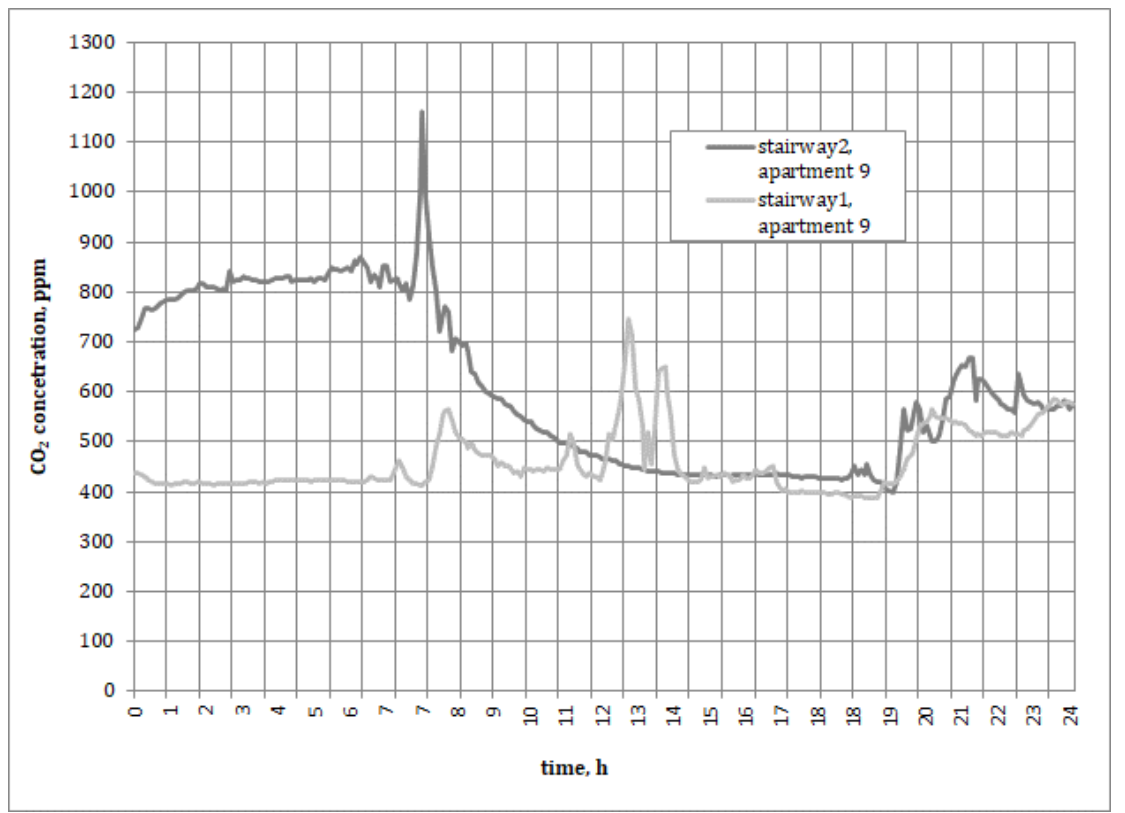

Fig. 4. Concentration of carbon dioxide [ppm] as a function of time (sampling time: $5 \mathrm{~min}$ ) in apartment no. 9 ( 3 rd floor) in staircase no. 1 (with natural ventilation) and in staircase no. 2 (with hybrid ventilation)

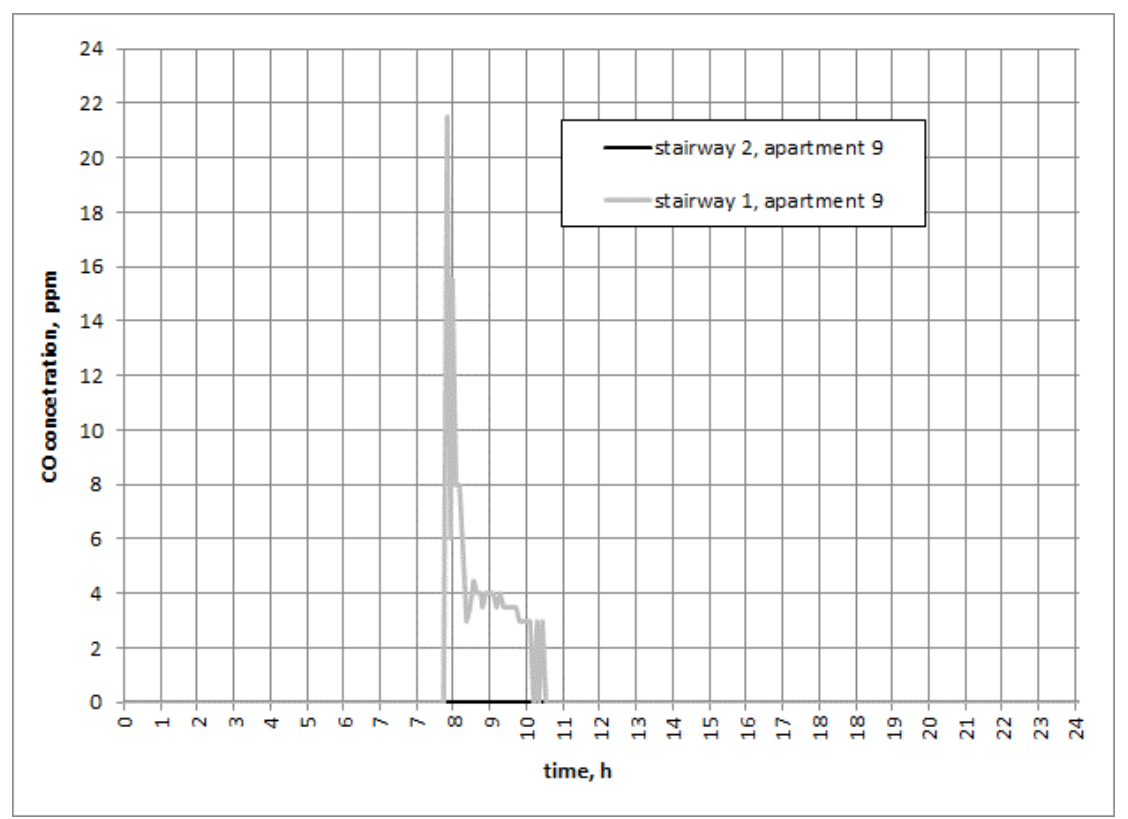

Fig. 5. Carbon monoxide concentration [ppm] as a function of time (sampling time: $5 \mathrm{~min}$.) in apartment no. 9 (3rd floor) in staircase no. 1 (with natural ventilation) and staircase no. 2 (with hybrid ventilation)

Compared to the reference apartment in staircase no. 2, equipped with the balanced hybrid ventilation system - the results of the measurements show a significant decrease in the concentration of carbon dioxide (Fig. 4), with maximum values of about $700 \mathrm{ppm}$, but no carbon monoxide CO (Fig. 5). 
As a result of measurements carried out in the apartment with natural ventilation, located in the examined staircase no. 1 , it was found that the safe level of carbon dioxide concentration, which is considered to be $400 \mathrm{ppm}$, was exceeded significantly (by over 300\%) and that small concentrations of carbon monoxide were observed in bathrooms. Compared to the reference apartment, in staircase no. 2 equipped with balanced hybrid ventilation, the results of the measurements indicate a significant improvement of the air quality. In terms of carbon dioxide concentrations, there has been more than a twofold decrease, with maximum values of around $700 \mathrm{ppm}$, while there has been no carbon monoxide in the reference apartment.

The results presented are those of a single continuous measurement carried out on the 8th of May. However, the same results were achieved repeatedly during the study, which indicates a visible improvement in indoor air quality in the staircase 2, where a hybrid, balanced pressure ventilation system was used.

Therefore, it should be concluded that the presence of carbon monoxide and exceeding $\mathrm{CO}_{2}$ concentrations require new solutions to be applied in existing buildings without the need to subject them to major alterations.

\section{Conclusions}

It appeared that buildings equipped with natural ventilation are strongly exposed to the weather conditions, (especially external air temperature and external air density) which causes natural ventilation to be less effective. As a result of this it is clear that we can expect worse indoor air quality.

On the other hand we could observe a better situation in the staircase equipped with the hybrid ventilation system: lower levels of carbon dioxide and a lack of carbon monoxide.

The use of a hybrid balanced ventilation system in existing buildings seems justified, however it should be remembered that in most cases these buildings are equipped with gasfired instantaneous water heaters, which makes it impossible to apply the above solutions under the applicable Building Law and Technical Conditions to which buildings and their location should conform.

Therefore, additional and more detailed research in this area should be carried out in order to raise awareness and make an impact on the legislator with regard to opening up to new solutions and introducing changes in the Building Law and Technical Conditions with which buildings and their location should be compliant.

\section{Acknowlegements}

This scientific research was funded by the statute subvention of Czestochowa University of Technology, Faculty of Infrastructure and Environment.

\section{References}

[1] Caussen G., de Oliveira Fermandes E., Fanger P.O., 1996 European data base on indoor air pollution sources in buildings. Indoor Air'96, Nagoya.

[2] Lis P., The optimal amount of air for the natural ventilation of classrooms as a function of the rate of outdoor air leakage for windows, Zeszyty Naukowe Politechniki Częstochowskiej 2020, Seria Budownictwo nr 26, 108-113.

[3] Lis P., Cechy budynków edukacyjnych a zużycie ciepła do ogrzewania, Wydawnictwo Politechniki Częstochowskiej, Częstochowa 2013.

[4] Sowa J., Proces migracji zanieczyszczeń powietrza w budynkach w warunkach stochastycznych zakłóceń, Politechnika Warszawska, Warszawa 1995.

[5] Lubina P., Badanie zmienności wewnętrznych zysków ciepła z uwagi na dynamikę potrzeb cieplnych w budynkach, Praca doktorska (niepublikowana), Politechnika Śląska, Gliwice 2004.

[6] Nantka M.B., Modele matematyczne naturalnych procesów wymiany powietrza w budynkach mieszkalnych, Zeszyty Naukowe Politechniki Śląskiej 1990, Inżynieria Środowiska, 32, 47-77. 
[7] Fanger P.O., Lauridsen J., Bluyssen P., Clausen G., Air pollution sources in offices and assembly halls, quantified by the olf unit, Energy and Buildings 1988, 12, 7-19.

[8] Świerc A., Tąta D., Foit H., Lubina P., Foit W., Pomiar intensywności wentylacji naturalnej istniejącego budynku, Część 1. Rozważania wstępne, Ciepłownictwo, Ogrzewnictwo, Wentylacja 2016, 11/47, 476-479.

[9] PN-83/B-03430/Az3:2000 Wentylacja w budynkach mieszkalnych zamieszkania zbiorowego i użyteczności publicznej - Wymagania.

[10] Miśniakiewicz E., Wymiana powietrza w pomieszczeniach mieszkalnych i jej wpływ na jakość powietrza wewnętrznego, Praca doktorska (niepublikowana), Opole 2002.

[11] Nantka M.B., Metody pomiaru wymiany powietrza w budynkach mieszkalnych, Zeszyty Naukowe Politechniki Śląskiej 1990, Inżynieria Środowiska, 32, 27-46.

[12] Nantka M.B., Problemy identyfikacji przepływów i wymiany powietrza w budynkach wielostrefowych z wentylacją naturalną, Zeszyty Naukowe Politechniki Śląskiej 1993, Inżynieria Środowiska, 36.

[13] Stolarska M., Series of monographs innovations - sustainability - modernity - openness energy ISMO 2019. Printing House of Bialystok University of Technology, Bialystok 2019, 39, 73-82.

\section{Wentylacja naturalna a jakość powietrza wewnętrznego w budynkach mieszkalnych wielorodzinnych - wskazanie problemu, studium przypadku}

\section{STRESZCZENIE:}

Istniejace i projektowane budynki mieszkalne powinny zapewniać mieszkańcom odpowiednie warunki mikroklimatu wewnętrznego zarówno pod względem komfortu cieplnego, jak i jakości powietrza w pomieszczeniach. Silne tendencje do oszczędzania energii w budynkach przyczyniają się do stosowania materiałów o lepszej izolacyjności termicznej (ściany) i szczelności (drzwi i okna). W ciagu ostatnich kilku lat pojawiła się tendencja do hermetycznego uszczelniania budynków. Zjawisko to można zaobserwować zarówno w starych remontowanych budynkach, jak i nowych lub termomodernizowanych. Jednocześnie, w budynkach nowych oraz istniejących stosowane są tradycyjne rozwiązania wentylacji grawitacyjnej. W takich przypadkach działanie wentylacji staje się istotnym czynnikiem do realizacji wymagań jakości powietrza w pomieszczeniach. Przedstawiono wybrane wyniki badań dotyczących tej problematyki, ujmujące temat $\mathrm{w}$ nowym świetle, $\mathrm{z}$ możliwością wykorzystania nowych technologii, takich jak wentylacja hybrydowa, w istniejących budynkach. Uzyskano je drogą kompleksowych pomiarów w istniejących budynkach mieszkalnych. Celem opracowania jest zaprezentowanie i podsumowanie wstępnych badań opisujących wpływ wentylacji naturalnej i hybrydowej oraz szczelności przegród na stan środowiska wewnętrznego.

\section{SŁOWA KLUCZOWE:}

jakość powietrza wewnętrznego; wentylacja naturalna; wentylacja hybrydowa; budynki mieszkalne wielorodzinne 